\title{
Trigeneration Systems: A Review
}

\author{
Sunil Bagade ${ }^{1}$, Prasad Rampure ${ }^{2}$, Mahesh Shelar ${ }^{3}$, Sharad Mahajan $^{4}$ \\ Department of Mechanical Engineering ${ }^{1,2,3,4}$, Dr. Daulatrao Aher College of Engineering, Karad, India ${ }^{1}$, \\ KLE College of Engineering and Technology, Chokodi, India ${ }^{2}$, \\ K. K. Wagh Institute of Engg. Education and Research, Nashik, India ${ }^{3}$, \\ Email:sdb.mech@gmail.com ${ }^{1}$
}

\begin{abstract}
Trigeneration is combined generation of electricity, heat and cooling energy is being possible because of the commercial availability of absorption chillers. The components of trigeneration systems are prime movers i.e. diesel generator or natural gas engine, waste heat recovery boiler and vapour absorption system. Sizing of trigeneration systems is about selecting the trigeneration configuration and its system components and arriving at their capacities. Many studies were analysis studies and they do not size the system components. They restrict themselves to one or other kind of analysis thereby limiting their applicability. The first law analysis and economic analysis of trigeneration systems are the basic tools, evolved methods like exergy analysis and thermoeconomics analysis are being more rigorously applied. Some studies gives Environmental concerns like emissions. This paper reviews recent literature about trigeneration systems in which physical trigeneration systems are analysed and reports the analysis tools employed.
\end{abstract}

Keywords-First law, Second law, Thermoeconomics, Trigeneration.

\section{INTRODUCTION}

Energy is a crucial input to sustain life on the planet earth. Modern energy carriers have increased the quality of life through better services like lighting, cooking and transportation. However this has resulted in increased dependency on fossil fuels for growth. Increase in population as well as increased prosperity along with the reliance on fossil fuel based economic growth model has contributed to climate change.

India too has relied on fossil fuels with coal dominating the energy generation in 2005 (55\%). In the same year oil with its contribution of about $30 \%$ and natural gas with $9 \%$ are other important modern energy carriers in India. Hydro and nuclear energy contributing $6 \%$ and $1.0 \%$ respectively in 2005 are the other resources [1].

Waste Heat Recovery is an important measure in energy conservation. Heat energy rejected through heat engines is at lower temperature as compared to combustion temperatures and hence less valuable. So a large heat energy rejection does not automatically translate into scope of waste energy recovery. Whether recovery is feasible or not depends upon the quality of heat energy and the capital and running costs of waste heat recovery equipments. Waste heat recovery from boilers, kilns, ovens and furnaces or from Diesel generators is to be evaluated according to economic and exergy criteria.

\section{TRIGENERATION}

A Schematic of engine based trigeneration system is shown in Figure 1. Engine coupled generator generates electricity that is supplied to meet the power demand. Electricity production can be integrated with the grid or used locally as in off grid situations. Engine rejects the heat energy from engine body to water (coolant) as well as from exhaust gases. Water is used as a heat transfer fluid to recover this rejected energy. Water receives heat when circulating through the engine jacket. The hot water is used for hot or cold utility. The energy rejected by the engine through exhaust gases is used directly in the exhaust gas fired absorption chiller or indirectly harnessed by using water as the heat transfer fluid. The steam fired or hot water fired absorption chiller is used in such situations. The absorption chiller technology is mature and commercially available technology. Lithium bromide-water absorption chillers are used for air conditioning applications. Ammonia water absorption chillers are used for air conditioning and refrigeration applications.

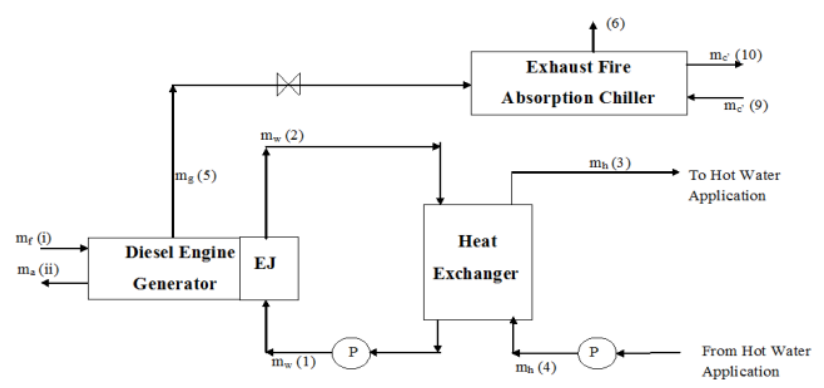

Fig. 1. Engine based trigeneration system

\section{ANALYSIS METHODS}

3.1. Simulation based Studies

The commonly used simulation softwares used were as follows.

Engineering Equation Solver is used for analysis of trigeneration system by few researchers. Nonlinear algebraic and differential equations solving, optimization and uncertainty analysis are the features of this software.

TRNSYS is a general purpose, modular, detailed computer simulation. Researchers Godefroy et al. [2] 
International Journal of Research in Advent Technology, Vol.7, No.5, May 2019

E-ISSN: 2321-9637

\section{Available online at www.ijrat.org}

used TRNSYS to analyse engine based trigeneration system. Pagliarini et al., [3] also used this TRNSYS software tool to simulate an engine based trigeneration plant in a hospital in Italy. The program is written in ANSI Standard Fortran. TRNSYS has tremendous flexibility due to its modularity but a user needs to have certain expertise to handle TRNSYS. The TRNSHELL program is an environment program that houses TRNSYS, the utility programs plus editing and plotting, and FORTRAN functions such as compiling and linking. The user needs knowledge of FORTRAN.

Cycle Tempo was another commercial software used by researchers to study trigeneration system. It has extensive and validated model library that includes conventional as well as innovative systems and components. Exergy analysis for optimization of the design and operation of trigeneration system is built in the software. There is a built in solver for large non-linear algebraic systems of equations, tailored to the special case of mass and energy balances. Colonna et al., [4] have done a system modeling study of engine driven and turbine driven ammonia chiller system using this simulation software cycle tempo. For engine driven system, the authors integrated a FORTRAN code based on mass and energy balance of engine with the commercial software.

Wang et al., [5] used the ECLIPSE simulation software to study the performance of diesel engine trigeneration. In a commercial building scale, another researcher used the same software model bio-fueled engine based trigeneration system. Huang et al., [6] researcher modeled a biomass fueled trigeneration system for buildings. Gasifier performance data obtained from experimentation was integrated with thermodynamic models of trigeneration components. Models were not restricted to first law principles. The physical system comprised of absorption chiller driven by exhaust gas energy while jacket water heat was used to meet the heating demand. The electricity was fed to the grid for meeting the power demand. The fuel was replaced by producer gas when gasifier was integrated with trigeneration system. The authors used ECLIPSE simulator to assess the performance of trigeneration system fed with different biomass fuels. Variation in cooling/heating demands was handled by thermal storage that was not modeled. The variation in electrical demand was taken care by sizing the engine at peak loads and visualizing a system that sells surplus excess power to grid. The software based on mass and energy balance though useful for sizing of trigeneration system excluded many important aspects like part load modeling and thermal storage modeling.

Self-coded softwares were also used in modelling and simulation studies. One such study on engine based trigeneration system was done by Espirito Santo [7]. He defined trigeneration as simultaneous production of power, heating and cooling and cogeneration as coproduction of heating and power. His paper presented a simulation methodology, which assumed the manufacturers data for modeling engine performance and thermodynamic properties and thermodynamic principles to model the physical phenomenon in other components of trigeneration. He considered the hourly load curve for a medium size hospital of brazil for simulating the performance of engine based trigeneration system under two operational strategies namely electricity demand following and full engine load following. $\mathrm{He}$ evaluated the system performance using primary energy savings and energy utilization factor based on first law analysis and exergy efficiency based on second law. Calculation procedures used were polynomial curve fitting for engine and absorption chiller performance. Thermodynamic models for engines and absorption chillers should have been included for better simulation. In simulation, he did not predict the engine sizes and chiller capacity but calculated performance parameters. In another study the same author developed a methodology based on annual energy demand profiles for sizing a trigeneration system for a hospital. Computational simulation programme was self-coded by the author Espirito Santo D.B, [8].

Diesel engine based trigeneration systems have been extensively modelled on the basis of energy, exergy and economics by Aysegul et al., [9]. Authors studied turbocharged engine. Exhaust gases leaving the turbocharger were used to generate steam in the waste heat recovery boiler. The other system components included compressor, intercooler, pump and condenser. Models and simulations were reported by Puig-Arnavat et al., [10], Angrisani et al., [11]. Borg and Kelly [12], and Marimón et al., [13]. Ali Nadi Unal et al [14] proposed an optimization methodology for trigeneration system. Giovanni Angrisani et al [15] went through various methods used by researchers to analyze polygeneration systems.

\subsection{Experimental Studies}

Researchers have also used experimentation approach to obtain crucial performance data of actual trigeneration systems. One such study is an experimental investigation on small capacity diesel engine driven trigeneration system by Lin et al [16]. They investigated the performance (first law efficiency) and specific carbon dioxide emissions of trigeneration system. They concluded that the trigeneration system is feasible as compared to standalone electricity only system. The authors did not size the system nor did they consider economic feasibility. They focused on technical feasibility or more aptly its workability. Arriving at the sizes of trigeneration components namely absorption chiller capacity and heater capacity for a given engine could have been an interesting contribution. The study was useful to understand efficiency and coefficient 
International Journal of Research in Advent Technology, Vol.7, No.5, May 2019

E-ISSN: 2321-9637

Available online at www.ijrat.org

Table 1. Summary of relevant literature.

\begin{tabular}{|c|c|c|}
\hline Reference & Type of study & Findings \\
\hline \multicolumn{3}{|c|}{ Modeling and simulation studies } \\
\hline Wang et al ., 2014 & $\begin{array}{l}\text { Modeling of I C Engine } \\
\text { primed trigeneration system } \\
\text { Energetic, Economic, } \\
\text { Environmental }\end{array}$ & $\begin{array}{l}\text { Based on energy the performance of engine } \\
>100 \mathrm{kWe} \text { was best. On environmental basis } \\
\text { about } 550 \mathrm{~kW} \text { was optimum and on economic } \\
\text { basis above } 500 \mathrm{~kW} \text { were recommended. }\end{array}$ \\
\hline $\begin{array}{l}\text { Rodriguez-Aumente } \\
\text { et al., } 2013\end{array}$ & $\begin{array}{l}\text { Modeling of I C Engine } \\
\text { primed trigeneration system } \\
\text { with solar } \\
\text { Energetic, Economic, } \\
\text { Environmental }\end{array}$ & $\begin{array}{l}\text { Energetic } \eta \% \text { increased from } 78 \text { to } 82 \% \\
\text { Primary energy savings (PES)increased from } \\
30 \% \text { to } 38 \% \\
\text { Payback period increased from } 10.6 \text { years to } \\
11.6 \text { years } \\
\mathrm{CO}_{2} \text { reduction was } 1500 \text { ton/year without solar } \\
\text { and } 1760 \text { ton/year with solar }\end{array}$ \\
\hline Rosato et al., 2013 & $\begin{array}{l}\text { Modeling of I C Engine } \\
\text { primed trigeneration system } \\
\text { with solar } \\
\text { Energetic, Economic, } \\
\text { Environmental }\end{array}$ & $\begin{array}{l}\text { PES increased by } 13.4 \% \\
\mathrm{CO}_{2} \text { reduction by } 18.9 \% \\
\text { Operating costs reduced by } 20.9 \%\end{array}$ \\
\hline Espirito Santo,2012 & $\begin{array}{l}\text { Modeling of I C Engine } \\
\text { primed trigeneration system } \\
\text { Energetic, Exergetic }\end{array}$ & $\begin{array}{l}\text { Energy utilization factor was found to be } \\
\text { between } 60-80 \% \text { and first law efficiency } \\
\text { between } 35-38 \% \text {. }\end{array}$ \\
\hline Ebrahimi et al., 2012 & $\begin{array}{l}\text { Modeling and simulation } \\
\text { study to assess impact of } \\
\text { climate on the diesel engine } \\
\text { size }\end{array}$ & $\begin{array}{l}\text { Fuel energy saving ratio was calculated for } \\
\text { different regions and it varied range of } 25 \% \text { to } \\
38 \% \text {. Trigeneration efficiency of } 85 \% \\
\text { reported. }\end{array}$ \\
\hline Huang et al.,2011 & $\begin{array}{l}\text { Modeling of biomass fueled } \\
\text { Engine primed trigeneration } \\
\text { system } \\
\text { Energetic, Economic, } \\
\text { Environmental }\end{array}$ & $\begin{array}{l}\text { Trigeneration efficiency on NCV basis } \\
\text { reported an increase up to } 59 \% \text { while } \mathrm{CO}_{2} \\
\text { emissions were down upto } 60 \% \text {. } \\
\text { Environmental } \mathrm{CO}_{2} \text { reduction upto } 62 \% \\
\text { High capital investment about } 2600 £ / \mathrm{kWe}\end{array}$ \\
\hline Wang Y et al.,2011 & $\begin{array}{l}\text { Modeling of I C Engine } \\
\text { primed trigeneration } \\
\text { systems fired with diesel or } \\
\text { hydrogen } \\
\text { Energetic, Environmental }\end{array}$ & $\begin{array}{l}\text { With diesel fuel: } \eta \mathrm{t}=80 \% \\
\text { Environmental Emissions of } \mathrm{CO}_{2} \text { around } 0.3 \\
\mathrm{~g} / \mathrm{kWh} \\
\text { With hydrogen fuel is used: } \eta \mathrm{t}=83 \% \\
\text { Emissions of } \mathrm{CO}_{2}=\text { zero }\end{array}$ \\
\hline Balli et al., 2010 & $\begin{array}{l}\text { Modeling of I C Engine } \\
\text { primed trigeneration system } \\
\text { Exergy } \\
\text { Economic }\end{array}$ & $\begin{array}{l}\text { Energetic } \eta \mathrm{t} \%=59 \% \\
\text { Electrical equivalent } \eta \mathrm{e}=48 \% \\
\text { exergetic cost also calculated }\end{array}$ \\
\hline \multicolumn{3}{|l|}{ Experimental studies } \\
\hline $\begin{array}{l}\text { Angrisani } \\
\text { et al.,2012 }\end{array}$ & Micro-trigeneration & $\begin{array}{l}\text { Cogeneration can give } \mathrm{Pe}=5.4 \mathrm{~kW} \text { with: } \\
\mathrm{PES} \text { increased by } 19 \%, \mathrm{CO}_{2} \& \text { by } 26 \% . \\
\text { Operational cost savings is reported as } 30 \% . \\
\text { Trigeneration costs are higher }\end{array}$ \\
\hline Khatri et al.,2010 & $\begin{array}{l}\text { Experimentation on Diesel } \\
\text { engine based micro- } \\
\text { trigeneration }\end{array}$ & $\begin{array}{l}\eta t \% \text { increased from about } 34 \% \text { to about } \\
86 \% \text {. Fuel consumption and } \mathrm{CO}_{2} \text { reduced by } \\
\text { about } 61 \% \text { became about } 0.12 \mathrm{~kg} / \mathrm{kW} \mathrm{h}\end{array}$ \\
\hline
\end{tabular}

of performance (COP) variation when the engine operates at off design loads. Another study on experimentation concentrated on the energy recovery from diesel engine exhaust gases which provided crucial data in designing actual engine based trigeneration system by Shekh et al., [17] and Wenzhi et al., [18].
Pandiyarajan et al [19] considered a Diesel Engine driven waste recovery system with thermal storage using energy balance model. This study was however restricted to energy recovery and storage. Behaviour of thermal storage system while meeting the loads was not considered in the analysis. About 10-15\% energy from exhaust gases was reported to have been recovered. Energy recovery from jacket water was 
International Journal of Research in Advent Technology, Vol.7, No.5, May 2019

E-ISSN: 2321-9637

\section{Available online at www.ijrat.org}

not attempted. Khatri et al., [20] reports findings from experimentation done on compression ignition engine based trigeneration to estimate and compare the performance with standalone system. Emissions were also measured and compared. Similar studies on micro trigeneration systems were done in the laboratory with the objective of performance assessment by Angrisani et al., [21] and Angrisani et al., [22].

Another experiment on a trigeneration system using a natural gas fired $952 \mathrm{cc}$ three cylinder engine with a water glycol mixture as a coolant in the engine jacket was reported by Rosato et al., [23]. Heat was recovered from the coolant in a plate heat exchanger by cold water circulated by a rotor pump whose speed was varied to change the flowrates. The hot water tank of $1000 \mathrm{~m}^{3}$ was provided to store the recovered heat. The tank was insulated with $50 \mathrm{~mm}$ polyurethane layer and was equipped with a $4 \mathrm{~kW}$ auxiliary heater. The recovered heat was used for meeting heating demand in winter and cooling demand in summer. The cooling demand was met by using a lithium chloride water based absorption system. The system could sense the tank temperature and stopped thermal recovery if the temperature exceeded the allowable maximum. This was done by passing the jacket water and sending it to radiator. No recovery from exhaust gases was considered. Underlying the need to establish the feasibility of using internal combustion based cogeneration systems in the residential sector, to conduct sensitivity and what if analysis, the authors reported experimental data on $6 \mathrm{~kW}$ nominal electrical output and $11.7 \mathrm{~kW}$ nominal thermal output engine under steady as well as transient modes of operation. The data so generated was input to combustion based cogeneration device model. Thus instead on relying on basic thermodynamic model, the cogeneration model was based on empirical data obtained from rigorous experimentation on a calibrated cogeneration unit. However, this model was not integrated with the load curve and that appears to be an important limitation in its applicability. Furthermore absorption cooling model was not included in this mathematical model leaving the user clueless on trigeneration feasibility of engine based systems. Dae H Lee et al. [24], and Rocha et al. [25] have reported findings of experimentation on trigeneration systems.

Dae H Lee et al., [26] considered a system comprising of $930 \mathrm{cc}, 12 \mathrm{~kW}$ engine generator with a secondary combustor, fin and tube heat exchanger and shell and tube heat exchanger for diesel engine energy recovery. This experimental set up and energy analysis were used to show that the total efficiency of engine could reach upto a maximum of $94.4 \%$ at a water flow rate of $20 \mathrm{lit} / \mathrm{min}$. Energy was recovered from both the exhaust gases as well as from engine parts by fin and tube and shell and tube heat exchangers respectively. Thermal storage was however not considered. Though not a study on trigeneration (since engine is not connected to cooling and heating demand), the experimentation on recovering energy from exhaust as well as jacket water gave useful insights that could be put to use in the mathematical modeling of energy recovery systems.

Some studies are not experimental but look into the actual data of actual engine systems. Aysegul et al., [27] in their paper analysed the actual data from a diesel engine powered cogeneration system comprising of three turbocharged, 18 cylinder diesel engine generators with totaled installed capacity of 25.3 MW and steam generation capacity of 8.1 tons/hr. They suggested an option of harnessing the energy of exhaust gases emerging from steam boiler for operating absorption refrigeration system. Bassols et al., [28] explained the application of trigeneration in food industry with the help of few case studies. They report on the existing trigeneration systems in food industry. Andrea Costa et al., [29] discussed the economic viability of trigeneration for an actual kraft pulp mill. Another study by Ziher et al., also looks into the economics of trigeneration in a hospital [30].

\section{CONCLUSION}

Trigeneration literature is dominated with studies on either engine driven or gas turbine driven systems. Systems with prime movers like fuel cells and Sterling engines are rarely reported.

Both ammonia vapour absorption systems as well as lithium bromide chillers were chosen as physical systems for meeting the cooling demand.

Though trigeneration finds feasibility when adopted at larger capacities, researchers have investigated even micro trigeneration systems both experimentally as well as analytically.

While first law analysis yielding energy saving was used commonly by authors often in combination with economic analysis and was a simple and powerful tool, some authors argued that it failed to capture the second law inefficiencies which were best addressed by obtaining exergy values.

Exergy values themselves were insufficient to point out at the costs involved in improving second law efficiency of trigeneration systems. Exergoeconomic analysis therefore appears to be a preferred choice in some recent works.

\section{REFERENCES}

[1] Bhattacharya, S.C.; Jana, C. (2009): Renewable energy in India: Historical developments and prospects. Energy 34, pp. 981-991.

[2] Godefroy, J.; Boukhanouf, R.; Riffat, S. (2007): Design, testing and mathematical modelling of a small-scale CHP and cooling system (small CHP-ejector trigeneration). Applied Thermal Engineering, 27, pp. 68-77. 
International Journal of Research in Advent Technology, Vol.7, No.5, May 2019

$$
\text { E-ISSN: 2321-9637 }
$$

\section{Available online at www.ijrat.org}

[3] Pagliarini, G.; Corradi, C.; Rainieri, S. (2012): Hospital CHCP system optimization assisted by TRNSYS building energy simulation tool. Applied Thermal Engineering, 44, pp. 150-158.

[4] Colonna, Piero.; Sandro, Gabrielli. (2003): Industrial trigeneration using ammonia-water absorption refrigeration systems. Applied Thermal Engineering, 23, pp. 381-396.

[5] Wang, J.; Wu, J.; Zheng, C. (2014): Analysis of tri-generation system in combined cooling and heating mode. Energy and Buildings, 72, pp. 353-360.

[6] Huang, Y.; Wang, Y.; Rezvani, S.; McIlveenWright, D.; Anderson, M.; Hewitt, N. (2011): Biomass Fueled Trigeneration System in Selected Buildings. Energy Conversion and Management, 52, pp. 2448-2454.

[7] Espirito Santo, D.B. (2012): Energy and exergy efficiency of a building internal combustion engine trigeneration system under two different operational strategies. Energy and Buildings, 53, pp. $28-38$.

[8] Espirito Santo, D.B. (2014): An energy and exergy analysis of a high-efficiency engine trigeneration system for a hospital: a case study methodology based on annual energy demand profiles. Energy and Buildings, 76, pp.185-198.

[9] Aysegul, Abusoglu.; Mehmet, Kanoglu. (2009): Exergoeconomic analysis and optimization of combined heat and power production: A review. Renewable and Sustainable Energy Reviews, 13, pp. 2295-2308.

[10] Puig-Arnavat, M.; Bruno, J. C.; Coronas, A. (2014): Modeling of Trigeneration configurations based on biomass gasification and comparison of performance. Applied Energy, 114, pp. 845-856.

[11] Angrisani, G.; Roselli, C.; Sasso M.; Tariello, F. (2014): Dynamic performance assessment of a micro-trigeneration system with a desiccantbased air handling unit in Southern Italy climatic conditions. Energy Conversion and Management, 80, pp.188-201.

[12] Borg, S. P.; Kelly, N. J. (2013): High resolution performance analysis of micro-trigeneration in an energy-efficient residential building. Energy and Buildings, 67, pp. 153-165.

[13] Marimon, M. A.; Arias, J.; Lundqvist, P.; Bruno, J. C.; Coronas, A. (2011): Integration of trigeneration in an indirect cascade refrigeration system in supermarkets. Energy and Buildings, 43(6), pp. 1427-1434.

[14] Ali Nadi, Unal.; Gulgun, Kayakutluc.; Ibrahim, Ersoz. (2016): Operational Optimization in Simple Tri-generation Systems. Applied Thermal Engineering, doi:10.1016/j.applthermaleng.2016. 06.059.

[15] Giovanni, A.; Atsushi, A.; Elisa, M.; Carlo, R.; Maurizio, S. (2016): Performance assessment of cogeneration and trigeneration systems for small scale applications. Energy Conversion and Management doi:10.1016/j.enconman.2016.03. 092.

[16]Lin, Lin.; Yaodong, Wang.; Tarik, AlShemmeri.; Tom, Ruxton.; Stuart, Turner.; Shengchuo, Zeng.; Jincheng, Huang.; Yunxin, He.; Xiaodong, Huang. (2007): An experimental investigation of a household size trigeneration. Applied Thermal Engineering, 27, pp. 576-585.

[17] Shekh, N. H.; Saiful, B. (2013): Waste heat recovery from the exhaust of a diesel generator using Rankine Cycle. Energy Conversion and Management, 75, pp. 141-151.

[18] Wenzhi, Gao.; Zhai, Junmeng.; Li, Guanghua.; Bian, Qiang.; Feng, Liming. (2013): Performance Evaluation and Experiment System for Waste Heat Recovery of Diesel Engine. Energy.55, pp. 226-235.

[19] Pandiyarajan, V.; Chinna Pandian, M.; Malan, E.; Velraj, R.; Seeniraj, R. (2011): Experimental Investigation on Heat Recovery from Diesel Engine Exhaust Using Finned Shell and Tube Heat Exchanger and Thermal Storage System. Applied Energy, 88, pp. 77-87.

[20] Khatri, K. K.; Sharma, D.; Soni, S. L.; Tanwar, D. (2010): Experimental investigation of CI engine operated micro-trigeneration system. Applied Thermal Engineering, 30(11-12), pp.1505-1509.

[21] Angrisani, G.; Rosato, A.; Roselli, C.; Sasso, M.; Sibilio, S. (2012): Experimental results of a micro-trigeneration installation. Applied Thermal Engineering, 38, pp. 78-90.

[22] Angrisani, G.; Minichiello, F.; Roselli, C.; Sasso, M. (2010): Desiccant HVAC system driven by a micro-CHP: experimental analysis. Energy and Buildings, 42(11), pp. 2028-2035.

[23] Rosato, A.; Sibilio, S. (2012): Calibration and validation of a model for simulating thermal and electric performance of an internal combustion engine-based micro-cogeneration device. Applied Thermal Engineering, 45-46, pp. 79-98.

[24] Dae, Hee Lee.; Jae, Suk Park.; Mi, Ra Ryu.; Jeong, Ho Park. (2010): Effects of secondary combustion on efficiencies and emission reduction in the diesel engine exhaust heat recovery system. Applied Energy, 87, pp. 17161721.

[25] Rocha, M.S.; Andreos, R.; Simões-Moreira, J. R. (2012): Performance tests of two small trigeneration pilot plants. Applied Thermal Engineering, 41, pp. 84-89.

[26]Dae, Hee Lee.; Jae, Suk Park.; Mi, Ra Ryu.; Jeong, Ho Park. (2013): Development of a highly efficient low-emission diesel enginepowered co-generation system and its optimization using Taguchi method. Applied Thermal Engineering, 50, pp. 491-495.

[27] Aysegul, Abusoglu.; Mehmet, Kanoglu. (2009): Exergetic and thermoeconomic analyses of 
International Journal of Research in Advent Technology, Vol.7, No.5, May 2019 E-ISSN: 2321-9637

\section{Available online at www.ijrat.org}

diesel engine powered cogeneration: Part 1 and Part 2. Applied Thermal Engineering, 29, pp. 234-241.

[28] Bassols, J.; Kuckelkorn, B.; Langreck, J.; Schneider, R.; Veelken, H. (2002): Trigeneration in the food industry. Applied Thermal Engineering, 22, pp. 595-602.

[29] Andrea, Costa.; Jean, Parisa.; Michael, Towers; Thomas, Browne. (2007): Economics of trigeneration in a kraft pulp mill for enhanced energy efficiency and reduced GHG emissions. Energy 32, pp. 474-481.

[30]Ziher, D.; Poredos, A. (2006): Economics of a trigeneration system in a hospital, Applied Thermal Engineering 26, 2006, pp. 680-687.

[31] Shelar, M.; Bagade, S.; Kulkarni, G. (2016): Energy and Exergy analysis of diesel engine powered trigeneration systems. Energy Procedia, 90 , pp. $27-37$. 